\title{
A SZERSZÁMGÉPEK MODULÁRIS TERVEZÉSE
}

\author{
KOLOZSVÁRI ZSOLT
}

ÖSSZEFOGLALÁS

Jelenleg a gépgyártásban, általában több tervezési módszert alkalmaznak, de ezek közül egyik sem bír kizáró jelleggel. A tervezó nem tud valamit megtervezni anélkül, hogy csupán csak egyetlen egy tervezési módszerhez folyamodjon, mivelhogy a tervezési módszerek szorosan kapcsolódnak egymáshoz.

A jelen dolgozatban, elốször rövid bemutatásra kerülnek a fóbb tervezési módszerek. kiemelve mindegyik jellegzetességeit és alkalmazási teruleteit. Továbbá rátérunk a moduláris tervezés részletes bemutatására. Mit takar ez a fogalom, milyen alkalmazási lehetőségei vannak a szerszámgéptervezés terén, milyen kapcsolat fưzi a többi tervezési módszerekhez, melyek a perspektívái. Bemutatjuk, hogy melyek a moduláris tervezés kritériumai, ezen módszerrel tervezett szerszámgépek felépítésének a követelményeit, a modulok fổb csoportosítási (agregálási) típusait, szó esik a tipizált kinematikus tengelyrendszerrốl, az adatbázisok feltöltésérốl és felhasználásáról. A dolgozat végsổ részében, egy szerszámgép orsófejének vázlatos tervezésének bemutatásával illusztráljuk a moduláris tervezést.

\section{ÁLTALÁNOS TUDNIVALÓK A SZERSZÁMGÉPEK TERVEZÉSÉVEL KAPCSOLATBAN}

Ahogy már az összefoglalóban említettük, a gépgyártás terén, általában, több tervezési módszert alkalmaznak, de viszont egyikük sem alkalmazható kizáró jelleggel a tervezés folyamatában, mivelhogy a tervezésben egy állandó kölcsönhatás észlelhetố a különböző módszerek között, amelyeknek külön-külön megvan a maga sajátossága a különbözớ alkalmazási területeken.

Manapság, a gépek többsége komplex felépítésú, magukban foglalnak mechanikus, pneumatikus, hidraulikus, elektromos, elektronikus komponenseket. Ezért, ezek tervezése csak egy jól felkészült szakemberekbő́l álló csapattal lehetséges, amelynek tagjai különböző területeken dolgozó szakemberek (mérnökök, gazdasági szakemberek, informatikusok).

A tervezés első szakasza a marketing kell hogy legyen, mert minden gyártmány első fontos tulajdonsága az kell legyen, hogy az illetố termék igényelt legyen a piacon.

Fontosabb tervezési módszerek közưl megemlítendók a moduláris tervezés módszere, az inverzió módszere, D.F.M.A..

$\mathrm{Az}$ inverzió módszerén alapuló tervezés egy rendszer komponenseinek funkcionális szerepének, alakjának és viszonylagos helyzetének felcserélési lehetôségén, a moduláris tervezés a rendszerek modulokból való felépítésén, a D.F.M.A. pedig a rendszerek komponenseinek optimizálásán alapszik.

\section{MODULÁRIS TER VEZÉSI MÓDSZER}

A szerszámgépek moduláris tervezését, többféle előnye (úgy a szállító, mint a felhasználó szemszögéból nézve) miatt, jelenleg mint az egyik legtöbbet használt tervezési módszert tartják számon. 
A rugalmas gyártórendszerek megjelenése után elképzelhetetlen ezek tervezése moduláris módszer alkalmazása nélkül.

Minden, a moduláris tervezés elvén gyártott szerszámgép, modulokból áll, amelyek több, más szerszámgép bizonyos egységeiben is, más összeállításban megtalálhatók. A moduláris elven gyártott szerszámgépek lehetôvé teszik egy meghatározott csoporthoz tartozó funkcionális szempontból autonóm, különböző méretứ és funkciójú modulokból való összeszerelését, lehetôvé téve így, hogy különbözó szerszámgépeket hozunk létre, amelyek a követelményeknek megfelelóen könnyen átalakíthatók, csupán az egyes modulok helyének változtatásával vagy éppenséggel helyettesítésével.

Ennek a tervezési módszernek a következó elónyei vannak:

-a tervezési idő csökkenése,

-a termékek folyamatos tökéletesítése,

-a költségek csökkenése,

-a karbantartási és termelési körülmények javítása.

Moduláris tervezéskor a szerszámgépeket a következő követelmények szerint csoportosíthatók: -tehnológiai kritériumok szerint a szerszámgépek lehetnek:

-forgási felületek megmunkálására alkalmasak;

-síkfelületek megmunkálására alkalmasak;

-komplex felületek megmunkálására alkalmasak;

-köpenyvázak megmunkálására alkalmasak.

A fentebb csoportok mindegyike továbbosztható más kritériumok szerint. Például, ha a síkfelületek vagy köpenyvázak megmunkálására alkalmas szerszámgépeket vesszük figyelembe, akkor ezek lehetnek:

-fúró - maró - dörzsölő gépek;

-fúró - dörzsölő gépek;

-fúró - maró - eszterga gépek.

vagy más kritérium szerint csoportosíthatjuk:

-egyorsós gépek;

-többorsós gépek stb.

A modulok kombinálása háromféleképpen lehetséges:

-az első típushoz azok a rendszerek tartoznak, amelyek lehetôvé teszik olyan szerszámgépek tervezését amelyek különböző méretú és anyagú, szimmetrikusan elhelyezkedó felületekkel bíró darabok megmunkálását teszi lehetơvé;

-a második típushoz tartozók már tökéletesebbek és lehetővé teszik olyan komplex darabok megmunkálását, amelyek nem csak méretben, hanem a megmunkálandó felületek térbeli elhelyezkedését illetően is különböznek;

-a harmadik típushoz azok a rendszerek tartoznak, amelyek az elóbb említett lehetôségeken kívül, még képesek különbözó gyártási feltételeknek is eleget tenni, figyelembe véve a munkadarabok változatosságát is.

A szerszámgépeknek tipizált modulokból való összeszerelésekor két fó kritériumot kell betartani: -a szerszámgépeket különálló modulokból kell összeszerelni, amelyeknek megvannak a maguk jól meghatározott szerepük, autonómak kinematikai szempontból;

-az egyes modulok nem szabad átvegyék a szomszédos modulok szerepkörét; ezzel a gépek átalakíthatósága rendkívül megnó.

Fontos tényező a szerszámgépek tervezésének terén, a szabványosított kinematikus tengelyremdszer, mivel hogy ez megkönnyíti a tervezést. Ilyen értelemben az egyenes mozgást végző tengelyek egy triéder alakú mértani koordinátarendszert képeznek, amelyben a fóorsó elmozdulási iránya a $\mathrm{Z}$ tengely irányának felel meg, az X és $\mathrm{Y}$ koordináták pedig az asztal síkjában fekszenek.

A szerszám forgási irányát az $X, Y$ és $Z$ tengelyek körül $A, B, C$-vel jelöjük.

Mivel egyes szerszámgépek mozgásai elég összetettek lehetnek, a fentebb említett fó tengelyeken kívül,még szabványosítottak a másodrendá $(\mathrm{U}, \mathrm{V}, \mathrm{Z})$ valimint a harmadrendú $(\mathrm{P}, \mathrm{Q}, \mathrm{R})$ koordinátarendszerek. 


\section{AZ ADATBÁZISOK ÖSSZEÁLLÍTÁSA ÉS FELHASZNÁLÁSA}

megírni.

Egy elốtolómú számítógépes tervezésekor, egy elổre megírt adatbázisra alapuló programot lehet

Tehát egy adatbázis felhasználása elốtt, ezt létre kell hozni egy külsố memóriaegységen. Ezen múvelet feltételezi egy állomány létrehozását, amely memorálja az adatbázist és az adatbázissal kapcsolatos adatokat, mint struktúra, rögzítések száma, stb.

$\mathrm{Az}$ adatbázis létrehozása nagyon fontos lépés egy informatikai rendszer létrehozásában. Egy ilyen rendszer tervezésekor két szakaszt különböztetünk meg:

-az analízis szakasza - amikor az informatizálandó problémát tanulmányozzuk, meghatározzuk a rendszer általános jellemvonásait (bemenetek, kimenetek, a rendszer feladatai, az adatbázis a saját struktúrájával együtt, programokra való lebontás. stb.);

-a programozás szakasza - amikor ténylegesen elkészítjük a rendszer programjait, létrehozzuk az adatbankot, stb.

A modularizáció, tipizálás és szabványosítás a szerszámgéptervezés olyan elemei amely lehetôvé teszi a fóbb modularizálandó elemek adatbázisának a létrehozását, valamint a szerszámgépek egységeinek számítógépes tervezését.

A mechanikai szerkezet megtervezésekor a következóket kell szem elótt tartani:

-szerszám és munkadarab kölcsönhatását;

-elötolás hossza;

-meghajtást.

Egy tervezési program bemeneti adatai a következók:

-a szán elốtolási hossza, amely szerint választják meg a vezérorsó hosszát illetve a vezeték méreteit;

-a munkafej elốtolási sebessége, amely értékétoól függ a meghajtás milyensége (legyen vagy sem átviteli arány) illetve a motor típusa;

-az előtolás pontossága (BLU-ban mérve), ami a jelátalakítók megválasztásánál illetve felépítésénél és a kinematikus tengelyrendszer felépítésénél játszik közre.

A mechanikai struktúra a forgácsolás általi megterhelése fó paramétere a mechanikai struktúra, a vezeték, vezérorsó és a motor, megválasztásának.

Ahhoz hogy minél jobb programokat állítsunk össze, az adatbázis minél több adattal való feltöltése, valamint a programnak egy grafikus tervezôprogramhoz (pl. ACAD) való hozzákapcsolása szükséges, ilyenképpen lehetôvé téve a teljes dokumentáció biztosítását a mechanikai struktúra tervezéséhez.

\section{EGY ELÖTOLÓMỨ MODULÁRIS TERVEZÉSÉNEK FELVÁZOLÁSA}

Egy szerszámgép elốtolómúv vének számítógépes tervezésekor az adatbázis magába kell foglalja a motor, vezérorsó és a vezeték méreteit. Tehát egy ilyen adatbázist ezeknek az elemeknek az adatai val kell feltölteni.

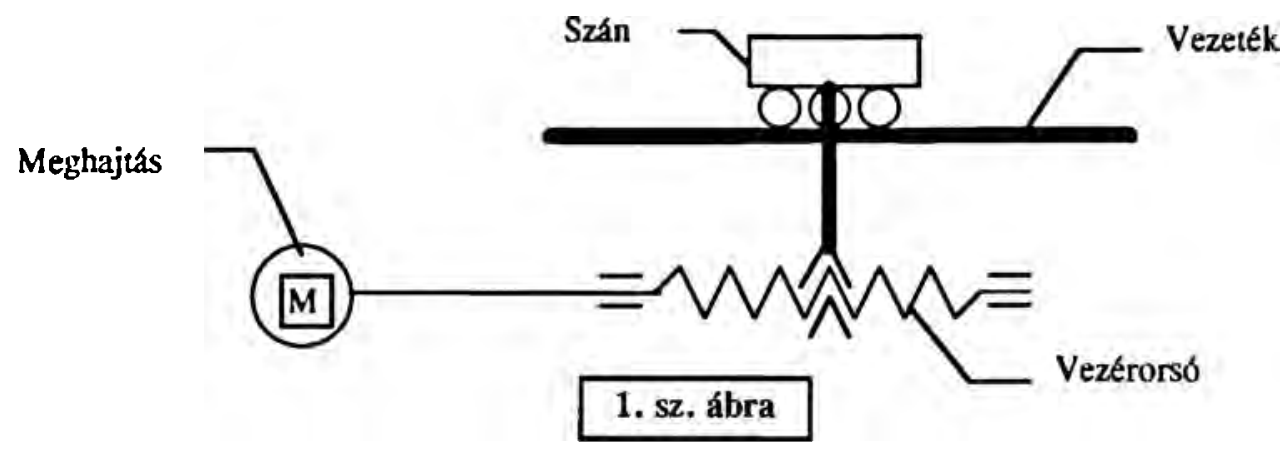




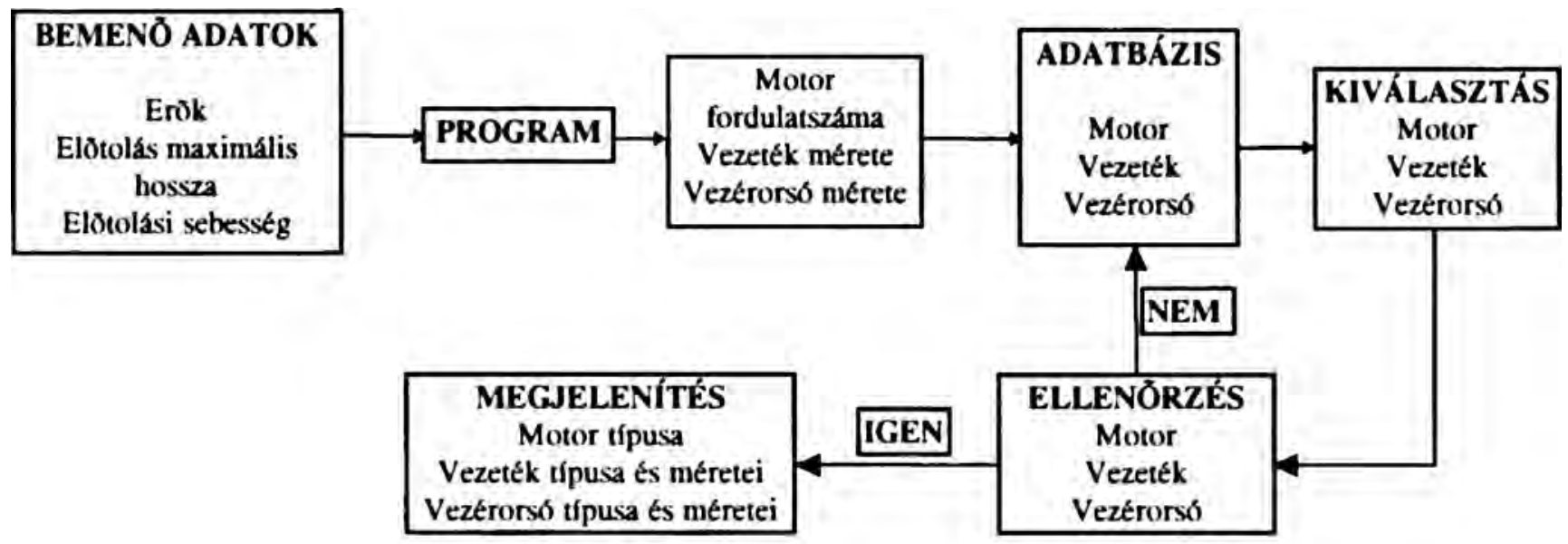

2. sz. ábra

Egy egyszerứ elotolómú (1. sz. ábra) tervezési folyamatát a 2. sz. ábrán szemléltetjük.

Egy elotolómú tervezésének moduláris tervezésekor figyelembe veszünk egy már adott adatbázist, amely tartalmazza a tipizált motorok, vezetékek és vezérorsók adatait. A bemenő adatok (forgácsoláskor fellépő erớk, előtolás maximális hossza, előtolási sebesség) birtokában egy számítógépprogram kiszámítja a motor szükséges fordulatszámát, a vezeték méreteit illetve a vezérorsó minimális átmérôjét és hosszát. Ezeket az eredményeket összehasonlítva az adatbázisban tárolt értékekkel, a program segítségével kiválasztjuk a megfelelố motort illetve a megfelelố méretú vezérorsót valamint vezetéket. Ha a kiválasztott alkatrészek nem kielégítóek, akkor a program visszatér az adatbázishoz és kiválasztja az következő nagyobb méretû́ alkatrészeket.

Kolozsvári Zsolt okl. gépészmérnök str. Dumbrava Roşie 37, Kolozsvár Tel.: 137913 